ZOOLOGIA 30 (6): 592-600, December, 2013

http://dx.doi.org/10.1590/S1984-46702013005000002

\title{
Larval and adult density of the porcellanid crab Petrolisthes armatus (Anomura: Porcellanidae) in an Amazon estuary, northern Brazil
}

\author{
Danielly Brito de Oliveira1,2, Dalila Costa Silva ${ }^{1} \&$ Jussara Moretto Martinelli-Lemos ${ }^{1}$
}

\author{
${ }^{1}$ Laboratório de Biologia Pesqueira e Manejo dos Recursos Aquáticos, Instituto de Ciências Biológicas, Grupo de Pesquisa em \\ Ecologia de Crustáceos da Amazônia, Universidade Federal do Pará. Avenida Perimetral 2651, Montese, Belém, PA, Brazil. \\ 2 Corresponding author. E-mail: danybrito@ufpa.br
}

\begin{abstract}
Petrolisthes armatus (Gibbes, 1850) is a porcellanid crab with a wide geographical distribution. In the present study we analyzed variations in the abundance of $P$. armatus adults and larvae over an annual cycle in the Marapanim estuary of the Amazon coastal zone, in the northeastern portion of the state of Pará, Brazil. Particularly, we focused on the presence of ovigerous females and timing of larval release, with the aim of elucidating reproductive patterns in a tropical estuarine system. The mean density of $P$. armatus larvae (zoea I and II) correlated positively with the salinity of the shallow waters of the estuary, whereas the abundance of adults correlated with the salinity registered in water samples collected from the benthic environment. There was also a significant positive correlation between larval density (zoea I and II) and water temperature. Ovigerous females were captured throughout the study period, from August 2006 to July 2007, but were more abundant in June and less abundant during the rainy months, between February and May. Larvae were only present during the dry season and transition months (June to January), and were absent during the rainy season (February to May). Petrolisthes armatus reproduces throughout the year in the Marapanim estuary and all developmental stages of this species (zoeal stages I and II, megalopae and adults) are found in the estuary. The results indicate that the study area is an important environment for the reproduction of this decapod.
\end{abstract}

KEY WORDS. Decapoda; macrobenthos; reproduction; zooplankton.

The porcellanids are typical crustaceans, with a pelagic larval phase. Larvae disperse in the water column, where they feed and grow. This is followed by a benthic phase associated with the substrate (QUEIROGA \& BLANTON 2005). Most porcellanid species pass through two zoeal stages prior to the molt that gives rise to the megalopae (Osawa \& McLaughuin 2010).

Porcellanid crabs can be found in tropical, subtropical, and temperate coastal waters all over the world (Veloso 1999). As adults, some species are symbionts of macroinvertebrates (BAEZA 2007), occurring, for example, in association with colonies of the polychaete Phragmatopoma lapidosa Kinberg, 1867 (Micheletti-Flores \& Negreiros-Fransozo 1999, Fransozo \& Bertini 2001).

Porcellanidae Haworth, 1825 comprises about 277 species and Petrolisthes Stimpson, 1858 is the most species-rich genus of this group (Osawa \& McLaughuin 2010, Ahyong et al. 2011), with approximately 100 species (RodríGuez et al. 2005, De Grave et al. 2009, Osawa \& McLaughuin 2010), many of which inhabit estuaries and mangroves (Miranda \& Mantelatto 2009). The morphology of the zoeal stages have been described for 32 species (HERnández et al. 2007), and a great deal of information is available on their embryology and distribution (Díaz-FERGUSON et al. 2008).
Petrolisthes armatus (Gibbes, 1850) is the most widely distributed species of the genus, being found in the western and eastern Atlantic, and eastern Pacific (Melo 1999). In Brazil, $P$. armatus has been recorded off the northeastern coast (Fernando de Noronha Island) and in Santa Catarina, in the extreme South (Melo 1999). On the northern coast, this species has been recorded in Maranhão and, more recently, in Pará (Melo 1999, Barros \& Pimentel 2001). The spatial distribution, population structure, and development patterns of $P$. armatus has been studied in oceanic beach and estuarine environments in the southern and southeastern Brazil (Oliveira \& Masunari 1995, Masunari \& Dubiaski-Silva 1998, Miranda \& Mantelatto 2009, 2010a).

Although most of the porcellanid species that occur on the Brazilian coast are found in the region between Pará (northern Brazil) and Espírito Santo (southeastern Brazil), few data are available on this group from the equatorial region (VELoso 1999). Ten porcellanid species occur on the coast of Pará: $P$. armatus, P. galathinus (Bosc, 1802), Porcellana sayana (Leach, 1820), P. sigsbeiana A. Milne-Edwards, 1880, Minyocerus angustus (Dana, 1852), Pachycheles ackleianus A. Milne-Edwards, 1880, P. greeleyi (Rathbun, 1900), P. rugimanus A. Milne-Edwards, 1880, Megalobrachium mortenseni Haig, 1962 and Pisidia brasiliensis 
Haig, 1968 (Melo 1999, Barros \& Pimentel 2001), although $P$. armatus is the predominant species in the estuarine environments of this region. This species is found primarily in the midlittoral and subtidal zones (MASUnARI \& DUBIASKI-Silva 1998), where it has an impact on benthic communities, such as oyster beds (Hollebone \& Hay 2008).

The larval development of $P$. armatus was first investigated by Lebour (1943), who described zoeal stages I and II, whereas Gore $(1970,1972)$ described the complete larval development of specimens from the Atlantic and Pacific oceans, respectively. Brossi-Garcia \& Moreira (1996) also described the juvenile instars of this species.

Stillman \& Somero (2000) and Stillman (2002) studied the thermal tolerance of a number of porcellanids, including $P$. armatus, and the consequences of this tolerance for their geographic distribution. The associations of these species with sandbanks formed by polychaetes and as a host for an isopod species have also been reported (Oliveira \& Masunari 1998, 2006, Micheletti-Flores \& Negreiros-Fransozo 1999, Bosa \& Masunari 2002, Miranda \& Mantellato 2010b). A number of other studies have also focused on the ecological features of the species, abundance patterns, and the morphology of the larval stages (Lima et al. 2005, Magris \& Loureiro-Fernandes 2005, DíazFerguson et al. 2008, Tilburg et al. 2010, Melo Jr et al. 2012).

The only information available for $P$. armatus from the Amazon estuary is the first record of this species in the region (Barros \& Pimentel 2001) and descriptions of the stomachs of larvae and post-larvae (Lima et al. 2005). No published data on the reproductive biology or life cycle of $P$. armatus are currently available. In the present study we analyzed the variations in the abundance of $P$. armatus larvae and adults over an annual cycle in an estuary of the Amazon coast (Marapanim). We focused on the periods when the largest numbers of ovigerous females were present, and the timing of larval release in this tropical environment.

\section{MATERIAL AND METHODS}

The northern Brazilian coast is 1,200 km long. It encompasses the mouth of the world's largest river in length and freshwater and sediment discharge, as well as the largest continuous tract of mangrove forest (SouzA FILHo et al. 2009). This region is also characterized by macro-tides, low water transparency and a predominance of sandy and muddy bottoms (SouzA FilHo et al. 2009, Krumme \& Saint-Paul 2010).

The waters of the Marapanim estuary are well mixed, being influenced by the semi-diurnal macrotides (amplitude $>5$ m) (BERRÊDo et al. 2008). In the municipality of Marapanim, monthly precipitation is highest in February $(760.60 \mathrm{~mm}$ ) (ANA 2007), which is typical of the region's climate, characterized by a rainy season between February and May (Moraes et al. 2005).

Three distinct climatic phases can be identified in this region (Oliveira et al. 2012): the dry season (August to Decem- ber), transition periods (January and June to July) and the rainy season (February to May). Mean temperatures range from $27^{\circ} \mathrm{C}$ in the rainy season to $29^{\circ} \mathrm{C}$ in the dry season (BERRêDo et al. 2008). The $\mathrm{pH}$ becomes higher during the rainy season (from 5.74 to 6.68 ) because of the intense influx of organic acids produced by the mangroves (24-60 g/kg) (BERRÊDo et al. 2008).

Larvae and adults of $P$. armatus were collected in the estuary of the Marapanim River, which is located in the Brazilian state of Pará, part of the Amazon coastal zone, and known locally as the "Salgado paraense". "Salgado", which means salty, is a reference to the fact that this region is dominated by the Atlantic Ocean, in contrast with the sector of the coast further west, which is under the influence of the discharge of the Amazon River.

The municipality of Marapanim is located between the Mãe Grande de Curuçá (Brasil 2002b) and the Maracanã (BrasiL 2002c) extractive reserves, which are sustainable-use protected areas, as defined by the Brazilian National Conservation System (BRASIL 2002a). Both reserves are important for the protection of local mangrove ecosystems and the subsistence and cultural identity of local communities (Iвама 2006).

All developmental stages of $P$. armatus collected at Marapanim were deposited in the Museu Paraense Emílio Goeldi, Pará, Brazil, under catalog numbers: MPEG 1120 (adults), MPEG 1121 (zoea I larvae), MPEG 1122 (zoea II larvae) and MPEG 1123 (megalopae).

Adult specimens of $P$. armatus were collected monthly between August, 2006 and July, 2007, at four sites in the Marapanim estuary. Sites A1 $\left(0^{\circ} 38^{\prime} 12^{\prime \prime} S, 47^{\circ} 38^{\prime} 74^{\prime \prime} \mathrm{W}\right)$ and B1 $\left(0^{\circ} 36^{\prime} 14^{\prime \prime} \mathrm{S}, 47^{\circ} 35^{\prime} 15^{\prime \prime} \mathrm{W}\right)$ are located close to the mouth of the estuary, while sites A2 $\left(0^{\circ} 42^{\prime} 38^{\prime \prime} \mathrm{S}, 47^{\circ} 41^{\prime} 23^{\prime \prime} \mathrm{W}\right)$ and B2 $\left(0^{\circ} 43^{\prime} 43^{\prime \prime} \mathrm{S}, 47^{\circ} 39^{\prime} 35^{\prime \prime} \mathrm{W}\right)$ are located upstream from the intermediate sector (Fig. 1), the same experimental design published by Oliveira et al. (2012). At each site, three subsamples were obtained from the hard substrate (composed by boulders and smaller fragments of rocks) in the upper and lower mid-littoral, with a total of 288 samples.

The sampling unit was a $0.5 \mathrm{~m} \times 0.5 \mathrm{~m}$ quadrat of PVC tubing. The sampling sites were selected randomly during low tide, when the substrate was exposed. The sites were located equidistantly, following a horizontal line perpendicular to the margin of the estuary. The porcellanid crabs present in each quadrat were removed manually and the substratum was sieved ( $3 \mathrm{~mm}$ of mesh size) in order to facilitate collection of specimens. The individuals were kept on ice before being fixed in glycerol, and were subsequently stored at the Laboratório de Biologia Pesqueira e Manejo dos Recursos Aquáticos, Universidade Federal do Pará, Brazil.

During collection, samples of water were obtained from the rock pools in which the adult $P$. armatus were found, with a $3 \mathrm{~mL}$ syringe, for the determination of salinity, using an optical refractometer (Atago). Data on monthly precipitation were obtained during the study period and long-term means were 
taken from the National Water Agency (ANA 2007). The temperature was recorded only for the zooplankton samples. A multiparameter analyzer was used to measure temperatures in situ, during collecting. It was not possible to measure the temperature of the benthic samples due to the reduced volume of water.

In the laboratory, the specimens were counted and identified to species using the identification key available in Melo (1999). Males and females were identified based on Oliveira \& MASUNARI (1995). The abundance of benthic specimens were estimated by dividing the number of individuals collected in each quadrat by its area $\left(0.25 \mathrm{~m}^{2}\right)$, multiplied by 4 to obtain the number of individuals per $\mathrm{m}^{2}$.

Zooplankton samples were obtained from six sites located along the margins of the Marapanim estuary. The western margin, with the town of Marapanim, and three fishing villages (Araticum, Aracumirim, and Alegria), suffers stronger anthropogenic impact. Three sites were selected on this margin, A1, A2 and A3, at distances of $4.7 \mathrm{~km}(\mathrm{~A} 1-\mathrm{A} 2)$ and $6.7 \mathrm{~km}$ (A2-A3) from one another. The other three sites, B1, B2 and B3 were established on the eastern margin of the estuary, which is virtually uninhabited. The distance between B1 and B2 was $8.2 \mathrm{~km}$, and that between B2 and B3, $8.7 \mathrm{~km}$ (Fig. 1).

We attempted to establish sites B1, B2, and B3 exactly opposite to the corresponding points of profile A. In some cases it was not possible due to the presence of sandbanks or rocky outcrops. These sites also corresponded to the estuary's gradient of salinity, with zone I (A1 + B1) closest to the open sea, zone II $(\mathrm{A} 2+\mathrm{B} 2)$ intermediate, and zone III $(\mathrm{A} 3+\mathrm{B} 3)$ in the innermost portion of the estuary, where salinity is lowest.

The temperature and $\mathrm{pH}$ of the water were measured during the collection of specimens from all six sites using a YSI multiparameter analyzer. Water samples were collected in polyethylene flasks for the analysis of salinity in the laboratory, using an optical refractometer (Atago).

Zooplankton samples were collected by horizontal surface trawls using a conical-cylindrical net $(200 \mu \mathrm{m}$ of mesh size) equipped with a flowmeter at the mouth. The specimens were fixed in a formalin solution (4\%). A total of 144 samples were collected, two samples from each site over the 12 months of the study period.

Each sample (1 L) was subdivided in a Folsom Plankton Splitter, following the procedure described by BoLtovsкoy (1981). A volume of $250 \mathrm{~mL}$ was established as the standard sample for the analysis of the larvae of $P$. armatus. These larvae were separated from the other zooplankton, analyzed under a Zeiss optical microscope, dissected, and identified as zoeal stages I or II, based on the studies of Gore $(1970,1972)$.

The volume of water filtered during the trawls was based on $\mathrm{V}=\mathrm{A}^{*} \mathrm{R}^{*} \mathrm{C}$, where $\mathrm{V}=$ the volume of water in $\mathrm{m}^{3}, \mathrm{~A}=$ opening of the net in $\mathrm{m}^{2}$ (for a $0.5 \mathrm{~m}$ diameter opening, $\mathrm{A}=0.19625$ $\left.\mathrm{m}^{2}\right), \mathrm{R}=$ number of rotations recorded on the flowmeter before and after each trawl (FF-FI), and $\mathrm{C}=$ standardization factor

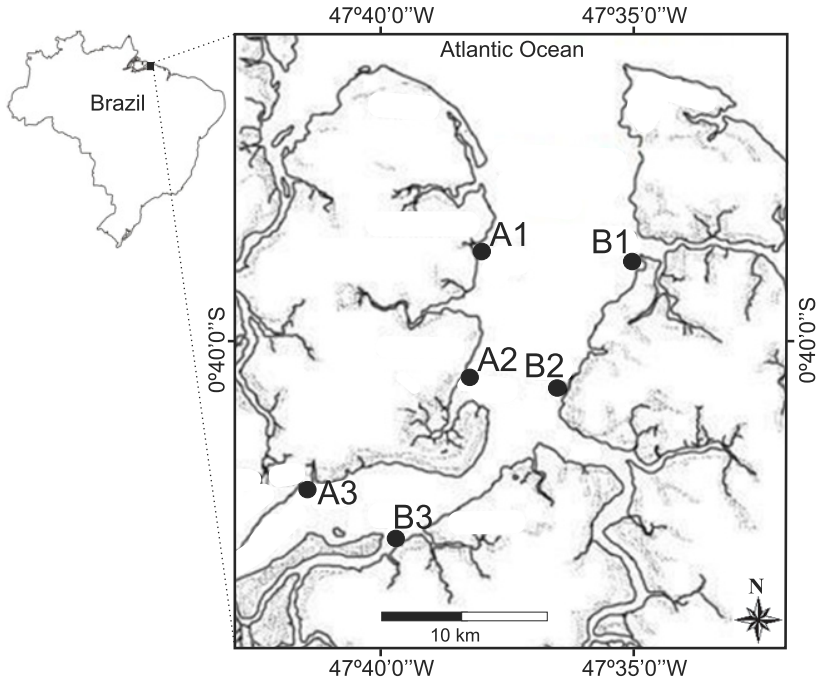

Figure 1 . Sampling sites $(\bullet)$ where the larvae and adults of Petrolisthes armatus were monthly collected at Marapanim estuary, northern Brazilian coast, between August 2006 and July 2007.

following calibration of the flowmeter $(C=0.32)$. The density of $P$. armatus larvae was calculated by $\mathrm{D}=n / \mathrm{V}$, where $n=$ number of larvae collected during the sampling, and $\mathrm{V}=$ volume of water filtered by the net $\left(\mathrm{m}^{3}\right)$, expressed as larvae per $100 \mathrm{~m}^{3}$.

The variation in the abiotic factors and the density of the larvae and adults of $P$. armatus during the study period August, 2006, through July, 2007 - was evaluated using the Kruskal-Wallis nonparametric analysis of variance, given the lack of normality or homocedasticity of the data, even after the data had been transformed (logarithmic and square root). The possible relationship between the density of $P$. armatus and abiotic variables was evaluated using the Spearman's correlation coefficient. All analyses were run in BioEstat 5.0 ${ }^{\circledR}$ (Ayres et al. 2007), considering $\alpha=0.05$.

\section{RESULTS}

The mean and standard deviation of the environmental parameters recorded in the shallow waters of the Marapanim estuary were $28.6 \pm 0.5^{\circ} \mathrm{C}$ for temperature; $7.8 \pm 0.6$ for $\mathrm{pH}$; and $19 \pm 9.7$ for salinity. The mean salinity was $17.5 \pm 10.4$ in all sites where adult $P$. armatus were collected (benthic environment).

The temperature, $\mathrm{pH}$, and salinity of the estuary water varied significantly among months (temperature: $\mathrm{H}=70.56, \mathrm{p}$ < 0.01; pH: $\mathrm{H}=24.47, \mathrm{p}=0.01$; salinity: $\mathrm{H}=122.18$, $\mathrm{p}<0.01$ ) (Figs 2-4). The median temperature was highest between August $($ median $=28.8$, min. $=28.4, \max .=29.7)$ and January ( median $=29$, $\min .=28.6, \max .=29.4)$, dropped in February $($ median $=27.7$, min. $=27.5, \max .=28)($ Fig. 2$)$. 
The $\mathrm{pH}$ was significantly higher during the transition and rainiest months $(\mathrm{H}=24.47, \mathrm{p}=0.01)$, between January $($ median $=8.1, \min .=5.7, \max .=8.8)$ and March $($ median $=$ 8.3, $\min .=7.6, \max .=8.9)($ Fig. 3$)$.

As salinity did not vary significantly between the shallow water and the rock-pools $(\mathrm{H}=1.81, \mathrm{p}=0.18)$, the monthly median of pooled values are presented in Fig. 4. In this case, significantly higher values $(\mathrm{H}=122.18, \mathrm{p}<0.01)$ were recorded during the dry season, between August (median $=28.5$, range $=$ 20-33) and December (median $=30$, range $=26-31$ ), with intermediate values being recorded during the transition month of January, and the lowest values during the rainiest months, between February (median $=8$, range $=6-8$ ) and July (median $=17.5$, range $=13-24)$ (Fig. 4 ).

The highest abundance of $P$. armatus larvae recorded during the study period was 269.35 zoea $\mathrm{I} / 100 \mathrm{~m}^{3}$ and 172.15 zoea $\mathrm{II} / 100 \mathrm{~m}^{3}$ (Table I). Larval density was significantly higher $(\mathrm{H}=$ $31.84, \mathrm{p}<0.01$ ) during the drier and transition months, in particular in October, 2006, when the highest median values were determined. Also, we registered two peaks of larval abundance, in December, 2006, and July, 2007 (Fig. 5). The monthly variation in density was the opposite of that found for the larvae, with significantly higher densities recorded in January (transition month) and February (rainy month) (Fig. 6).

Table I. Abundance and density of $P$. armatus at different stages of development recorded in the Marapanim Estuary, Pará (Brazil), between August 2006 and July 2007.

\begin{tabular}{|c|c|c|c|c|c|}
\hline \multirow{3}{*}{$\begin{array}{l}\text { Developmental } \\
\text { stage }\end{array}$} & \multirow{3}{*}{$\mathrm{N}$} & \multicolumn{4}{|c|}{ Density } \\
\hline & & \multicolumn{2}{|c|}{ Individuals $/ \mathrm{m}^{2}$} & \multicolumn{2}{|c|}{ Larvae/100 $\mathrm{m}^{3}$} \\
\hline & & Min. & Max. & Min. & Max. \\
\hline Zoea I & 694 & - & - & 0 & 269.35 \\
\hline Zoea II & 268 & - & - & 0 & 172.15 \\
\hline Megalopa & 9 & 0 & 64 & - & - \\
\hline Adult & 2,580 & 16 & 14,960 & - & - \\
\hline
\end{tabular}

The mean density of $P$. armatus larvae (zoea I and II) correlated positively with the salinity of the shallow waters of the estuary, whereas that of the adults collected from the rocky outcrops correlated with the salinity of the benthos, but the density of megalopae did not (Table II). There was also a significant correlation between the density of larvae (zoea I and II) and the temperature of the estuarine waters (Table II).

Ovigerous $P$. armatus females were collected throughout the year, but were less common during the rainy months, from February to May. Larvae were collected only during the dry season and transition months, i.e. August-January, June, and July (Fig. 7), and were absent in the rainy season (FebruaryMay). Megalopae were collected between boulders only in August, October, January, and February, with the highest density
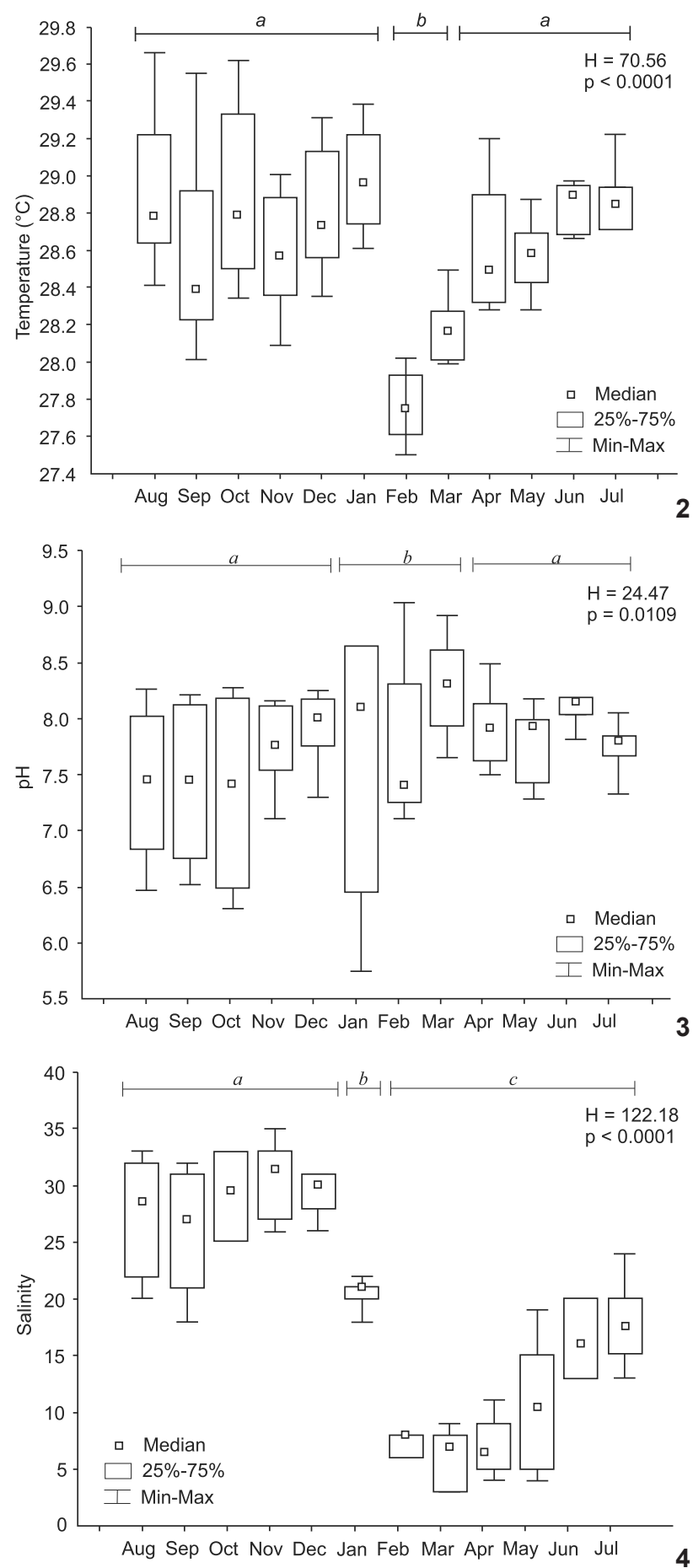

Figures 2-4. Monthly variation in the abiotic factors of the Marapanim Estuary, Brazil, between August 2006 and July 2007. (2) Temperature; (3) pH (shallow waters); (4) salinity (shallow waters). Distinct letters represent significant differences between months $(\alpha=0.05)$. 

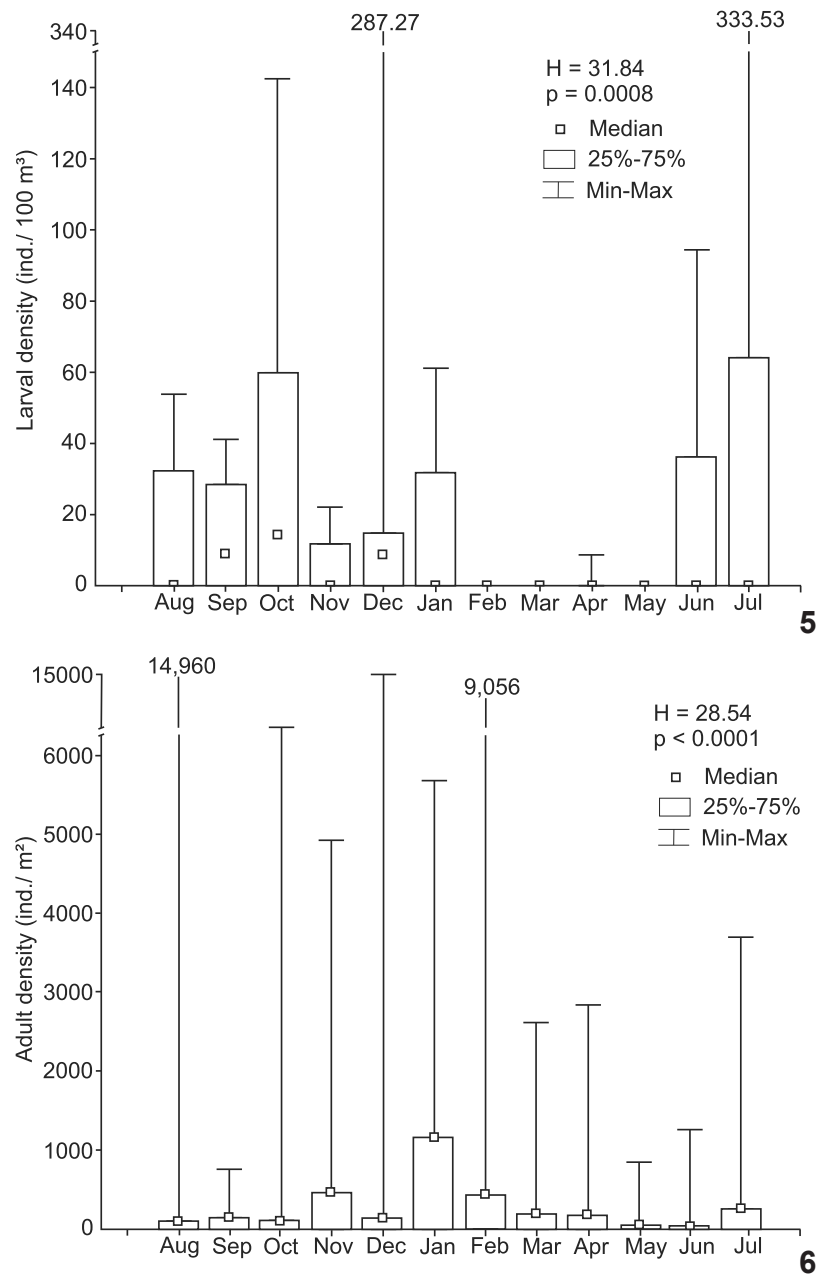

Figures 5-6. Density of Petrolisthes armatus in the Marapanim Estuary, Brazil, between August 2006 and July 2007: (5) larvae zoea I and II; (6) adults.

Table II. Spearman coefficients for the correlation between the density of $P$. armatus (larvae and adults) and abiotic factors. Significant values in bold script $(p<0.05)$.

\begin{tabular}{lccccccccccc}
\hline \multirow{2}{*}{ Stage } & Temperature & $\mathrm{p}$ & $\mathrm{pH}$ & $\mathrm{p}$ & \multicolumn{6}{c}{ Salinity } \\
\cline { 6 - 11 } & & & & & $\begin{array}{c}\text { Main } \\
\text { channel }\end{array}$ & $\mathrm{p}$ & Benthos & $\mathrm{p}$ \\
\hline Zoea I & 0.69 & 0.01 & -0.29 & 0.36 & 0.61 & 0.03 & - & - \\
Zoea II & 0.58 & 0.04 & -0.36 & 0.25 & 0.64 & 0.02 & - & - \\
Megalopae & - & - & - & - & - & - & 0.10 & 0.76 \\
Adult & - & - & - & - & - & - & 0.37 & 0.04 \\
\hline
\end{tabular}

being recorded in August, with 64 individuals per $\mathrm{m}^{2}$ (Fig. 8). In August and October all developmental stages of $P$. armatus were collected, including ovigerous females (Fig. 8).

Significant peaks of abundance of zoea I $(\mathrm{H}=31.84$, p < 0.01 ) occurred in December, 2006, with approximately 500 lar$\mathrm{vae} / 100 \mathrm{~m}^{3}$, and in July, 2007, with just over 450 larvae/100 $\mathrm{m}^{3}$. Peaks of zoea II abundance were recorded in July, 2007, October, 2006, and December, 2006, with approximately 297, 143 , and 128 larvae $/ 100 \mathrm{~m}^{3}$, respectively (Fig. 8).
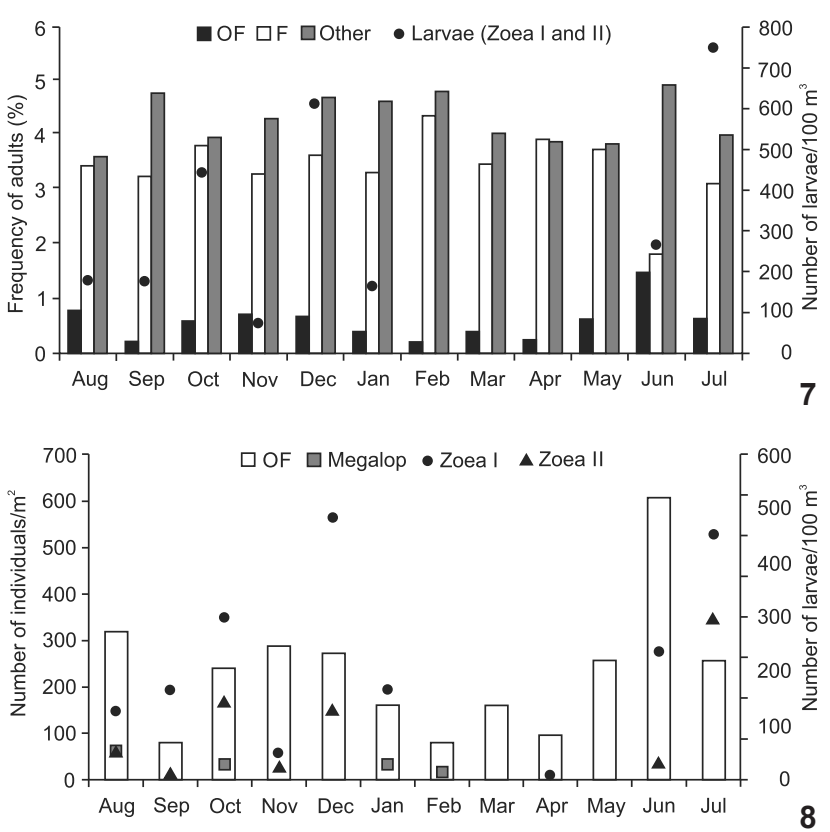

Figures 7-8. Relative abundance of Petrolisthes armatus larvae and ovigerous females collected monthly between August, 2006, and July, 2007, in the Marapanim Estuary, Pará, Brazil: (7) relative frequency (\%) of adults and density of larvae (number of larvae per $100 \mathrm{~m}^{3}$ ); (8) density of adults and megalopae (individuals per $\mathrm{m}^{2}$ ) and larvae, zoeal stages I and II (larvae per $100 \mathrm{~m}^{3}$ ). OF = ovigerous females; $F=$ non-ovigerous females; Others = megalopae and males .

\section{DISCUSSION}

The densities of $P$. armatus adults in tropical regions such as the Marapanim estuary in Northern Brazil tend to be higher than those recorded in colder regions. This pattern can be observed on the Brazilian coast. In the present study (tropical) maximum densities of $P$. armatus adults were observed in August, with 14,960 individuals $/ \mathrm{m}^{2}$, and in February, with 9,056 individuals $/ \mathrm{m}^{2}$. Masunari \& Dubiaski-Silva (1998) and Oliveira $\&$ Masunari (1995), by contrast, recorded maximum densities of approximately 668 and 305 individuals $/ \mathrm{m}^{2}$, in the south coast (subtropical) and Miranda \& Mantelatto (2009) collected a total of 775 specimens over the course of a year on the coast of the State of São Paulo (subtropical).

The higher density of $P$. armatus adults recorded in tropical regions may reflect the relatively successful recruitment of 
this species in these environments, although the integrated knowledge on all stages of the life cycle (covering both planktonic and benthic environments) will provide a better understanding of population dynamics of this decapod species (DíAz-FerGuson et al. 2008). In the present study, all the developmental stages of $P$. armatus (zoea I, zoea II and megalopa) were considered, allowing the identification of the period of most intensive reproductive activity and also the developmental strategies of this species. Petrolisthes armatus reproduces throughout the year in the Marapanim estuary, in the Amazon coastal zone, although ovigerous females were most common in June (at the end of the rainy season) and August (dry season). All life stages (zoea I and II, megalopa and adults) can be found in the estuary. The abundance of adults was high throughout the study period (August 2006 through July 2007), which implies that the study area is important for the development of this decapod species, and therefore for its conservation.

The spawning of decapod species in tropical estuaries tends to be continuous throughout the year, in contrast with temperate estuaries (Dittel \& Eiffanio 1990). Fransozo \& Bertini (2001) identified some porcellanid species that present seasonal reproduction, and others that breed throughout the year. Petrolisthes boscii (Audovim, 1826), P. rufescens (Heller, 1861), P. elongatus (H. Milne Edwards, 1837), and P. vanderhorsli Haig, 1956 are all known to reproduce seasonally in some parts of the world (Lewis 1960, Wear 1965, Ahmed \& Mustaquim 1974). Gebauer et al. (2007) recorded a distinct pattern in P. laevigatus in southern Chile, with an 11-month breeding season, starting at the end of the summer, and ending in the middle of the subsequent summer.

The Marapanim estuary offers favorable temperature conditions for reproduction throughout the year, with mean temperatures of between $27^{\circ} \mathrm{C}$ and $30^{\circ} \mathrm{C}$. This intensive breeding activity enables $P$. armatus to colonize the region successfully, with densities of 41,280 individuals $/ \mathrm{m}^{2}$. DíAz-Ferguson \& VARGAS-ZAMORA (2001) collected a total of 15,382 P. armatus crabs in the tropical Gulf of Nicoya in Costa Rica, between December 1997 and November 1998, with a maximum density of almost 100 individuals $/ \mathrm{m}^{2}$. Other decapod species also reproduce throughout the year in the Marapanim estuary, such as the thalassinidean shrimps Lepidophthalmus siriboia Felder \& Rodrigues, 1993 and Upogebia vasquezi Ngoc-Ho, 1989 (Oliveira et al. 2012, Silva \& Martinelli-Lemos 2012).

The reproductive period of the species of the suborder Pleocyemata is normally defined according to the abundance of ovigerous females in different periods of the year (SANT'ANNA et al. 2009), an approach also used for $P$. armatus in southeastern Brazil (Miranda \& Mantelatto 2009). Although two peaks of more intense reproductive activity were recorded - the first in the dry season (December), when the peak in the abundance of stage I zoea was recorded (483 larvae/100 $\mathrm{m}^{3}$ ), ovigerous females of $P$. armatus were observed throughout the year in the Marapanim estuary. The abundance of stage II zoea was also above 100 larvae/100 $\mathrm{m}^{3}$, while megalopae were recorded in the subsequent months, January (dry-rainy transition) and February (early rainy season), indicating the beginning of the recruitment period.

During the rainy months (February through May), the density of ovigerous females was lower, and no larvae were collected (excepted on April). Our hypothesis is that the absence of larvae during this period is due to the fact that they do not survive when salinity is low. We do not believe that they are dragged out from the estuary to offshore waters. Larval development from hatching to the megalopa stage does not exceed one month in either the Atlantic (GoRe 1970) or the Pacific oceans (Gore 1972), which suggests that the larvae hatching between February and May are unable to survive when salinity is lower than 20 . The low density of zoea I in April may represent the small number of larvae that are able to survive the prevailing conditions, reinforcing the idea that they remain in the estuary.

The larval abundance increases in the end of the rainy season, when the environmental conditions begin to favor larval development, which means more saline waters. Salinity is a key factor in the structure and distribution of decapod larvae in tropical estuarine environments (ANGER 2003, MAGRIS \& Loureiro-Fernandes 2011). The dispersal and recruitment of larvae of estuarine crustaceans are strongly influenced by salinity (O'CONNOR \& EPIFANIO 1985). Salinity appears to be the principal factor influencing the breeding activity of $P$. armatus in the study area, as shown by the lower densities of ovigerous females and reduced numbers of larvae collected during the rainiest months (February-May), when salinity was significantly lower than in the dry season.

Similarly, the density of the thalassinid L. siriboia and $U$. vasquezi larvae in the Marapanim estuary is significantly higher during the dry season (Oliveira et al. 2012). The same pattern has also been recorded in a tropical estuary in Costa Rica, where the abundance of $P$. armatus larvae was significantly higher during the dry season, when the salinity of the water was higher (Díaz-Ferguson et al. 2008). In an estuary in the South Atlantic, Tilburg et al. (2010) also recorded significant variation in the density of $P$. armatus larvae in relation to salinity.

In other regions of the world, in particular the temperate zone, temperature is the principal factor influencing the reproductive patterns of decapod species, including porcellanids (Hernáez-Bové 2001, Emparanza 2007, Hollebone \& Hay 2007). As considerable seasonal fluctuations in salinity occur in coastal and estuarine environments, the decapod species that inhabit these areas adopt different strategies of development according to their physiological constraints (STRATHMAnN \& STRATHMANN 1982, Anger 2003, 2006). Some species, such as Ucides cordatus (Linnaeus, 1763) and Uca vocator (Herbst, 1804), export their early larval stages to offshore waters, which implies a more ample dispersal strategy (Diele \& Simith 2006, Simith \& Diele 2008, SimitH et al. 2012). Some estuarine crabs also increase their swimming 
activity at higher salinities to avoid being removed from the estuary (Queiroga \& Blanton 2005). In northeastern Brazil, Melo JR et al. (2012) found that P. armatus larvae were more concentrated in the midwater and surface during the flood tide, thus avoiding being removed to more internal regions. By contrast, these larvae were more concentrated at the bottom during the ebb tides, avoiding exportation, which suggested that $P$. armatus reproduces and spends its life cycle on the inner shelf, rather than the outer shelf (MeLo JR et al. 2012).

Dittel \& Epifanio (1990) found all larval stages of Pinnotheres spp. in the plankton of Gulf of Nicoya and suggested that this species reproduces in this region and that larvae are retained in the system. At Marapanim, P. armatus remains in the estuary throughout its life cycle, following the same reproductive strategy described by MeLo JR et al. (2012) for this species on the northeastern coast of Brazil. This hypothesis has yet to be tested experimentally, although the presence of all the developmental stages of $P$. armatus throughout the year at different locations within the Marapanim estuary reinforces the conclusion that this species passes through its larval phases on the inner shelf. Furthermore, $P$. armatus breeds throughout the year in this region and salinity is a key factor for its development.

\section{ACKNOWLEDGMENTS}

The authors thank the colleagues who helped with the collection of specimens in the field and Stephen Francis Ferrari for the translation of the text, which was supported by the research faculty of the Federal University of Pará (PROPESP/ UFPA) and the Research and Development Foundation (FADESP) through grant 02/2011. We would also like to thank the editor and reviewers for their revision and comments on the manuscript, which helped to improve it considerably. All experiments conducted in this study complied with current applicable Brazilian state and federal laws (process DIFAP/ IBAMA \# 02018.008516 94-2005). This study was supported by the Brazilian National Research Council (CNPq) through the CT-AMAZÔNIA project (J.M.M., grant 553106/2005-8) and graduate stipends (Danielly Brito de Oliveira, grant 132847/ 2008-6 CNPq and Dalila Costa Silva, grant CAPES).

\section{LITERATURE CITED}

Ahmed, M. \& J. Mustaquim. 1974. Population structure of four species of porcellanid crabs (Decapoda: Anomura) occurring on the coast of Karachi. Marine Biology 26: 173-182.

Ahyong, S.T.; J.K. Lowry; M. Alonso; R.N. Bamber; G.A. Boxshall; P. Castro; S. Gerken; J.S. Karaman; J.W. Goy; D.S. Jones; K. Meland; D.C. Rogers \& J. Svavarsson. 2011. Subphylum Crustacea Brünnich, 1772. In: Z.Q. ZhANG (Ed.) Animal biodiversity: An outline of higher-level classification and survey of taxonomic richness. Zootaxa 3148: 165-191.
ANA. 2007. Agência Nacional das Águas. Available on line at: http://hidroweb.ana.gov.br/HidroWeb.asp?TocItem $=1070 \&$ TipoReg=7\&MostraCon=true\&CriaArq=false\&TipoArq=0\&SerieHist=false [Accessed: June, 2013].

ANGER, K. 2003. Salinity as a key parameter in the larval biology of decapod crustaceans. Invertebrate Reproduction and Development 43 (1): 29-45.

Anger, K. 2006. Contributions of the larval biology to crustacean research: a review. Invertebrate Reproduction and Development 49 (3): 175-205.

Ayres, M.; M. Ayres Jr; D.L. Ayres \& A.S. Santos. 2007. BioEstat 5.0 Aplicações estatísticas nas áreas das ciências biológicas e médicas. Belém, Instituto de Desenvolvimento Sustentável Mamirauá/MCT/CNPq, 364p.

BAEZA, J.A. 2007. The origins of symbiosis as a lifestyle in marine crabs (genus Petrolisthes) from the eastern Pacific: Does interspecific competition play a role? Revista de Biología Marina y Oceanografía 42 (1): 7-21.

Barros, M.P. \& F.R. Pimentel. 2001. A fauna de Decapoda (Crustacea) do Estado do Pará, Brasil: lista preliminar das espécies. Boletim do Museu Paraense Emilio Goeldi, Série Zoologia, 17 (1): 15-41.

Berrêdo, J.F.; M.L. Costa \& M.P.S. Progene. 2008. Efeitos das variações sazonais do clima tropical úmido sobre as águas e sedimentos de manguezais do estuário do rio Marapanim, costa nordeste do Estado do Pará. Acta Amazonica 38 (3): 473-482.

Boltovskoy, D. 1981. Atlas del zooplancton del Atlántico sudoccidental y métodos de trabajo con el zooplancton marino. Mar del Plata, Instituto Nacional de Investigación y Desarollo Pesquero, 936p.

Bosa, C.R. \& S. Masunari. 2002. Crustáceos decápodos associado aos bancos de Phragmatopoma caudata (Kroyer) (Polychaeta, Sabellariidae) na Praia de Caiobá, Matinhos, Paraná. Revista Brasileira de Zoologia 19 (1): 117-133.

Brasil. 2002a. Decreto $\mathrm{n}^{\circ}$ 4.340, de 22 de agosto de 2002. Brasília, Diário Oficial da União. Available online at: http:/ /www.planalto.gov.br/ccivil_03/decreto/2002/d4340.htm [Accessed: June, 2013].

Brasil. 2002b. Decreto (s/n) de 13 de dezembro de 2002. Available online at: http://www.planalto.gov.br/ccivil_03/ dnn/2002/Dnn9774.htm [Accessed: June, 2013].

Brasil. 2002c. Decreto (s/n) de 13 de dezembro de 2002. Available online at: http://www2.camara.leg.br/legin/fed/ decret_sn/2002/decreto-296-13-dezembro-2002-489710publicacaooriginal-1-pe.html [Accessed: June, 2013].

Brossi-Garcia, A.L. \& R.G. Moreira. 1996. Biometrical and morphological studies of Petrolisthes armatus (Gibbes, 1850) juvenile stages obtained in laboratory conditions (Decapoda, Porcellanidae). Revista Brasileira de Biologia 56 (2): 231-243.

De Grave, S.; N.D. Pentcheff; S.T. Ahyong; T.Y. Chan; K.A. Crandall; P.C. Dworschak; D.L. Felder; R.M. Feldmann; C.H.J.M. Fransen; L.Y.D. Goulding; R. Lemaitre; M. Low; J.W. 
Martin; P.K.L. NG; C.E. Schweitzer; S.H. Tan; D. Tshudy \& R. WETZER. 2009. A classification of living and fossil genera of decapod crustaceans. The Raffles Bulletin of Zoology 21: 1-109.

Díaz-Ferguson, E. \& J.A. Vargas-Zamora. 2001. Abundance of Petrolisthes armatus (Crustacea: Porcellanidae) on a tropical estuarine intertidal rocky beach, Gulf of Nicoya estuary, Costa Rica. Revista de Biología Tropical 49 (2): 97-101.

Díaz-Ferguson, E.; D. Arroyo; A. Morales \& J.A. Vargas. 2008. Observaciones sobre la larva del cangrejo marino tropical (Decapoda: Porcellanidae) Petrolisthes armatus en el Golfo de Nicoya, Costa Rica. Revista de Biología Tropical 56 (3): 1209-1223.

Diele, K. \& D.J.B. Simith. 2006. Salinity tolerance of northern Brazilian mangrove crab larvae, Ucides cordatus (Ocypodidae): Necessity for larval export? Estuarine, Coastal and Shelf Science 68: 600-608. doi:10.1016/j.ecss.2006.03.012.

DitTel, A.I. \& C.E. Epifanio. 1990. Seasonal and tidal abundance of crab larvae in a tropical mangrove system, Gulf of Nicoya, Costa Rica. Marine Ecology Progress Series 65: 25-34.

Emparanza, E.J.M. 2007. Patterns of distribution of dominant porcelain crabs (Decapoda: Porcellanidae) under boulders in the intertidal of northern Chile. Journal of the Marine Biological Association of the United Kingdom 87: 523531. doi: 10.1017/S0025315407053611.

Fransozo, A. \& G. Bertini. 2001. Population structure and breeding period of Pachycheles monilifer (Dana) (Anomura, Porcellanidae) inhabiting sabellariid sand reefs from the littoral coast of São Paulo State, Brazil. Revista Brasileira de Zoologia 18 (1): 197-203.

Gebauer, P.; K. Paschke \& C.A. Moreno. 2007. Reproductive biology and population parameters of Petrolisthes laevigatus (Anomura: Porcellanidae) in southern Chile: consequences on recruitment. Journal of the Marine Biological Association of the United Kingdom 87: 729-734. doi: 10.1017/S0025315407055282.

Gore, R.H. 1970. Petrolisthes armatus: A redescription of larval development under laboratory conditions (Decapoda, Porcellanidae). Crustaceana 18 (1): 75-89.

Gore, R.H. 1972. Petrolisthes armatus (Gibbes, 1850): The development under laboratory conditions of larvae from a Pacific specimen (Decapoda, Porcellanidae). Crustaceana 22 (1): 67-83.

Hernáez-Bove, P. 2001. Producción y rendimiento reproductivo en Petrolisthes granulosus (Decapoda, Anomura, Porcellanidae) en diferentes localidades del norte de Chile: una comparación latitudinal. Investigaciones Marinas 29: 73-81.

Hernández, G.; J. Bolaños; I. Magán \& K. Graterol. 2007. Morfología de la primera zoea de los cangrejos marinos Petrolisthes haigae y P. nobilii (Decapoda: Porcellanidae). Revista de Biología Tropical 55: 879-887.

Hollebone, A.L. \& M.E. Hay. 2007. Population dynamics of the non-native crab Petrolisthes armatus invading the South
Atlantic Bight at densities of thousands $\mathrm{m}^{-2}$. Marine Ecology Progress Series 336: 211-223.

Hollebone, A.L. \& M.E. Hay. 2008. An invasive crab alters interaction webs in a marine community. Biological Invasions 10: 347-358. doi: 10.1007/s10530-007-9134-9.

IBAMA. 2006. Relatório Final do Projeto de Monitoramento da Atividade Pesqueira no litoral do Brasil - Projeto Estatpesca. Brasília, SEAP/PROZEE/IBAMA, 328p.

Krumme, U. \& U. Saint-Paul. 2010. Dynamics in mangrove fish assemblages on a macrotidal coast, p. 189-207. In: U. SAINTPaul \& H. Schneider (Eds). Mangrove Dynamics and Management in North Brazil. Berlin, Springer-Verlag, Ecological Studies 211, 402p.

doi 10.1007/978-3-642-13457-9_12.

Lebour, M.V. 1943. The larvae of the genus Porcellana (Crustacea, Decapoda) and related forms. Journal of the Marine Biological Association of the United Kingdom 25: 721737.

LEwIS, J.B. 1960. The fauna of rocky shores of Barbados, West Indies. Canadian Journal of Zoology 38: 391-435.

Lima, J.F.; F.A. Abrunhosa \& M.A. Melo. 2005. Development and functional morphology of the foregut of larvae and postlarvae of Petrolisthes armatus (Gibbes) (Decapoda, Porcellanidae). Revista Ciência Agronômica 36: 290-294.

Magris, R.A. \& L.F. Loureiro-Fernandes. 2005. Levantamento preliminar das larvas de Porcellanidae (Decapoda, Anomura) do sistema estuarino dos rios Piraquê-Açú e Piraquê-Mirim, Aracruz, Espírito Santo. Brazilian Journal of Aquatic Science and Technology 9: 49-54.

Magris, R.A. \& L.F. Loureiro-Fernandes. 2011. Diversity and distribution of estuarine decapod larvae (Crustacea: Decapoda: Anomura, Brachyura) in tropical southeastern Brazil. Zootaxa 2758: 26-42.

Masunari, S. \& J. Dubiaski-Silva. 1998. Crustacea Decapoda da praia rochosa da Ilha do Farol, Matinhos, Paraná. II. Distribuição espacial de densidade das populações. Revista Brasileira de Zoologia 15: 643-664.

Melo, G.A.S. 1999. Manual de identificação dos Crustacea Decapoda do litoral brasileiro: Anomura, Thalassinidea, Palinuridea e Astacidea. São Paulo, Plêiade/FAPESP, 551p.

Melo Jr, M.; R. Schwamborn; S. Neumann-Leitão \& M.N. Paranaguá. 2012. Abundance and instantaneous transport of Petrolisthes armatus (Gibbes, 1850) planktonic larvae in the Catuama inlet, Northeast Brazil. Anais da Academia Brasileira de Ciências 84 (1): 95-102.

Micheletti-Flores, C.V. \& M.L. Negreiros-Fransozo. 1999. Porcellanid crabs (Crustacea, Decapoda) inhabiting sand reefs built by Phragmatopoma lapidosa (Polychaeta, Sabellariidae) at Paranapuã beach, São Vicente, SP, Brazil. Revista Brasileira de Biologia 59: 63-73.

Miranda, I. \& F.L.M. Mantelatto. 2009. Estimating population features of the anomuran crab Petrolisthes armatus (Porcellanidae) in a remaining and impacted mangrove area of the 
western Atlantic. Journal of Natural History 43: 2027-2039. doi: 10.1080/00222930903094613.

Miranda, I. \& F.L.M. Mantelatto. 2010a. Sexual maturity and relative growth of the porcellanid crab Petrolisthes armatus (Gibbes, 1850) from a remnant mangrove area, southern Brazil. Nauplius 18: 87-93.

Miranda, I. \& F.L.M. Mantelatto. 2010b. Temporal dynamic of the relationship between the parasitic isopod Aporobopyrus curtatus (Crustacea: Isopoda: Bopyridae) and the anomuran crab Petrolisthes armatus (Crustacea: Decapoda: Porcellanidae) in southern Brazil. Latin American Journal of Aquatic Research 38: 210-217. doi: 10.3856/vol38-issue2-fulltext-5.

Moraes, B.C.; J.M.N. Costa; A.C.L. Costa \& M.H. Costa. 2005. Variação espacial e temporal da precipitação no estado do Pará. Acta Amazonica 35 (2): 207-214.

O'Connor, N.J. \& C.E. EPIFAnIo. 1985. The effect of salinity and recruitment of fiddler crab larvae. Journal of Crustacen Biology 5 (1): 137-145.

Oliveira, D.B.; D.C. Silva \& J.M. Martinelli. 2012. Density of larval and adult forms of the burrowing crustaceans Lepidophthalmus siriboia (Callianassidae) and Upogebia vasquezi (Upogebiidae) in an Amazon estuary, northern Brazil. Journal of the Marine Biological Association of the United Kingdom 92 (2): 295-303. doi:10.1017/ S002531541100097X.

Oliveira, E. \& S. Massunari. 1995. Estrutura populacional de Petrolisthes armatus (Gibbes) (Decapoda, Anomura, Porcellanidae) da Ilha do Farol, Matinhos, Paraná, Brasil. Revista Brasileira de Zoologia 12: 355-371.

Oliveira, E. \& S. Masunari. 1998. Population relationships between the parasite Aporobopyrus curtatus (Richardson, 1904) (Isopoda: Bopyridae) and one of its porcelain crab hosts Petrolisthes armatus (Gibbes, 1850) (Decapoda: Porcellanidae) from the Farol Island, southern Brazil. Journal of Natural History 32: 1707-1717.

Oliveira, E. \& S. Masunari. 2006. Distribuição temporal da densidade de Aporobopyrus curtatus (Richardson) (Crustacea, Isopoda, Bopyridae), um parasito de Petrolisthes armatus (Gibbes) (Crustacea, Anomura, Porcellanidae) na Ilha do Farol, Matinhos, Paraná, Brasil. Revista Brasileira de Zoologia 23: 1188-1195.

Osawa, M. \& P.A. Mclaughlin. 2010. Annotated checklist of anomuran decapod crustaceans of the world (exclusive of the Kiwaoidea and families Chirostylidae and Galatheidae of the Galatheoidea) part II - Porcellanidae. The Raffles Bulletin of Zoology 23: 109-129.

Queiroga, H. \& J. Blanton. 2005. Interactions between behaviour and physical forcing in the control of horizontal transport of decapod crustacean larvae. Advances in Marine Biology 47: 107-214.

Rodríguez, I.T.; G. Hernández \& D.L. Felder. 2005. Review of the Western Atlantic Porcellanidae (Crustacea: Decapoda: Anomura) with new records, systematic observations, and comments on biogeography. Caribbean Journal of Science 41: $544-582$.

Sant'anna, B.S.; A.L.D. Reigada \& M.A.A. Pinheiro. 2009. Population biology and reproduction of the hermit crab Clibanarius vittatus (Decapoda: Anomura) in an estuarine region of southern Brazil. Journal of the Marine Biological Association of the United Kingdom 89: 761-767. doi:10.1017/S0025315409003075.

Silva, D.C. \& J.M. Martinelli-Lemos. 2012. Species composition and abundance of the benthic community of Axiidea and Gebiidea (Crustacea: Decapoda) in the Marapanim Bay, Amazon estuary, northern Brazil. Zoologia 29 (2): 144-158. doi: 10.1590/S1984-46702012000200007.

Simith, D.J.B \& K. Diele. 2008. O efeito da salinidade no desenvolvimento larval do caranguejo-uçá, Ucides cordatus (Linnaeus, 1763) (Decapoda: Ocypodidae) no Norte do Brasil. Acta Amazonica 38 (2): 345-350.

Simith, D.J.B.; A.S. Souza; C.R. Maciel; F.A. Abrunhosa \& K. Diele. 2012. Influence of salinity on the larval development of the fiddler crab Uca vocator (Ocypodidae) as an indicator of ontogenetic migration towards offshore waters. Helgoland Marine Research 66: 77-85. doi: 10.1007/s10152-011-0249-0.

Souza Filho, P.W.M.; F.D. Gonçalves; S.W.P. Rodrigues; F.R. Costa \& F.P. Mirandas. 2009. Multi-sensor data fusion for geomorphological and environmental sensitivity index mapping in the Amazonian mangrove coast, Brazil. Journal of Coastal Research 56: 1592-1596.

STILLMAN, J.H. 2002. Causes and consequences of thermal tolerance limits in rocky intertidal porcelain crabs, genus Petrolisthes. Integrative and Comparative Biology 42: 790-796.

Stillman, J.H. \& G.N. Somero. 2000. A comparative analysis of the upper thermal tolerance limits of eastern Pacific porcelain crabs, genus Petrolisthes: influences of latitude, vertical zonation, acclimation, and phylogeny. Physiological and Biochemical Zoology 73: 200-208.

Strathmann, R.R. \& M.F. Strathmann. 1982. The relationship between adult size and brooding in marine invertebrates. The American Naturalist 119 (1): 91-101.

Tilburg, C.E.; J.E. SeaY; T.D. Bishop; H.L. Miller III \& C. Meile. 2010. Distribution and retention of Petrolisthes armatus in a coastal plain estuary: the role of vertical movement in larval transport. Estuarine, Coastal and Shelf Science 88: 260266. doi:10.1016/j.ecss.2010.04.004.

Veloso, V.G. 1999. Família Porcellanidae (caranguejos anomuros marinhos), p.398-405. In: L. BucKup \& G. BOND-BuckuP. (Eds). Os crustáceos do Rio Grande do Sul. Porto Alegre, Universidade Federal do Rio Grande do Sul, 504p.

WEAR, R.G. 1965. Breeding cycles and pre-zoea larva of Petrolisthes elongatus (Milne Edwards, 1837) (Crustacea, Decapoda). Transactions of the Royal Society of New Zealand 5: 169-175.

Submitted: 23.I.2013; Accepted: 26.VII.2013.

Editorial responsibility: Rosana M. da Rocha 